LIU, N., F. XING, O. U. Jinhan and Z. ShiJIE (1980): A preliminary study on quantitative inheritance of Hevea brasiliensis. I. (a): Estimates of broad sense heritability and genetic correlation of some clones. Chin. J. Trop. Crops 1: 32-41.

Milford, G. F. J., E. C. PAARDeKooper and C. Y. Ho (1969): Latex vessel plugging, its importance to yield and clonal behaviour. J. Rubber Res. Inst. Malays. 21: 274-282.

Narayanan, R., J. B. Gomez and K. T. Chen (1973): Some structural factors affecting the productibitiy of Hevea brasiliensis. II. Correlation studies between structural factors and yield. J. Rubber Res. Inst. Malays. 23: 285-297.

NGa, B. H. and S. Subramaniam (1974): Variation in Hevea brasiliensis. I. Yield and girth data of the 1937 hand pollinated seedlings. J. Rubber Res. Inst. Malays. 24: $69-74$

PAARDEKoOPER, E. C. and SANIT SAMOSORN (1969): Clonal variation in latex flow pattern. J. Rubber Res. Inst. Malays. 21: 264-273.

SethuRAJ, M. R. (1981): Yield components in Hevea brasiliensis. Theoretical considerations. Plant, Cell Environ. 4: 81-83.
Simmonds, N. W. (1979): Principles of Crop Improvement. Longman, London, $408 \mathrm{p}$.

Simmonds, N. W. (1989): Rubber breeding, pp. 85-124. In: Rubber, edited by C. C. WEBSTER and W. J. BAUlKWILL, Longman Scientific and Technical, U.S.A.

STEINHOFF, R. J. and R. J. HoFF (1971): Estimates of heritability of height growth in western white pine based on parent-progeny relationships. Silvae Genet. 20: $141-143$.

TAN, H. (1987): Strategies in rubber tree breeding, pp 28-63. In: Improving Vegetatively Propagated Crops, edited by A. J. АввотT and R. K. AtKin, Academic Press, London.

TAN, H., T. K. MukherJeE and S. Subramaniam (1975): Estimates of genetic parameters of certain characters in Hevea brasiliensis. Theor. Appl. Genet. 46: 181-190.

TAN, H. (1979): Heritabilities of six biometrical characters of single pair mating families in Hevea brasiliensis. J. Rubber Res. Inst. Malays. 27: 127-131.

ZoBel, B. and J. TALBERT (1984): Applied Forest Tree Improvement. Wiley, New York.

\title{
A combination of fruit and leaf morphology enables taxonomic classification of the complex Q. robur L. - Q. $x$ rosacea Bechst. - Q. petraea (Matt.) Liebl. in autochthonous stands in Flanders
}

\author{
By Kristine Vander Mijnsbrugge ${ }^{1), 4)}$, Luc De Cleene $^{2)}$ and Hans Beeckman ${ }^{3)}$
}

(Received 27 July 2010)

\begin{abstract}
Hybrids between Quercus robur and $Q$. petraea have been a sought topic of many studies in Europe during the last decades. Here, leaf and fruit morphology were studied in five oak stands where both species occur naturally intermixed. The stands are relicts of old, possibly medieval coppice wood. Twenty two leaf characters and nine fruit characters were assessed on three leaves and three fruits per tree and for thirty trees per stand. A principal component analysis (PCA) resulted in a bimodal distribution with restricted overlap along the first component when both leaf and fruit data were

1) Research Institute for Nature and Forest, Gaverstraat 4, 9500 Geraardsbergen, Belgium.

2) University College KaHo Sint-Lieven, Association KULeuven, Hospitaalstraat 23, 9100 Sint-Niklaas, Belgium.

${ }^{3}$ ) Royal Museum for Central Africa, Leuvense steenweg 13, 3080 Tervuren, Belgium

4) Corresponding Author: Kristine VAnder Misnsbrugge. Tel. +32 544371 46, Fax +32 54436160 .

E-Mail: kristine.vandermijnsbrugge@inbo.be
\end{abstract}

processed together. For leaf and fruit data separately, the analysis produced only continuous clusters of trees. Two types of putative hybrids can be defined that either show a petiole length of the leaf (PL) according to $Q$. robur and a petiole length of the fruit (FP1) according to $Q$. petraea, or vice versa. These hybrids cluster within both groups of the PCA analysis, but not all are situated close to or in the intermediate area between the groups. A lowered mean relative number of developed acorns in the hybrid groups in comparison to their putative maternal parent, based on the assumption of matroclinal inheritance of PL, is observed. This might indicate a reduced ability for successful fertilisation in the hybrids. These results suggest the presence of putative hybrids and introgressed forms within the morphological distinct $Q$. robur and $Q$. petraea groups and argument for a taxonomically defined $Q$. $x$ rosacea based on PL and FP1 limits.

Key words: Quercus robur, Q. petraea, Q. x rosacea, hybridisation, leaf and fruit morphology, number of undeveloped acorns, taxonomy. 


\section{Introduction}

Hybrid swarms have intrigued taxonomists ever since the origin of the species concept (ARNOLD, 1997) and natural hybridisation may have been an essential force in species evolution (e.g. BURKE and ARNOLD, 2001). In trees, natural hybridisation and introgression are thought to be one of the causes for the high levels of genetic diversity often observed (PETIT and HAMPE, 2006). Many related indigenous tree and shrub species hybridise naturally, such as Quercus spp., Tilia spp., Ulmus ssp., Alnus spp., Populus spp., Salix spp., Betula spp. and many shrubs belonging to the Rosaceae family (MAES, 2007). Especially the hybrids and introgressed individuals between $Q$. robur and $Q$. petraea, taxonomically defined as $Q$. $x$ rosacea, have been a sought topic of many morphological and genetic studies in Europe the last decades, the recent ones often combining both morphology and genetics (reviewed by e.g. KREMER et al., 2002; Viscosi et al., 2009). Already in 1976 Van Valen suggested an alternative species concept to accommodate this "awkward' taxonomic group (in KELLEHER et $a l ., 2005)$. Interspecific gene flow is common within the genus Quercus, owing to the absence of real reproductive barriers and natural hybridization has been proven in natural mixed populations (e.g. BACILIERI et al., 1996; STREIFF et al., 1999), including first generation hybrids (CURTU et al., 2009). In addition, recent Bayesian clustering on SSR typed European white oaks has suggested that hybridisation is a common phenomenon playing a significant role in evolution of the oak species (LEPAIS et al., 2009). Still, several studies of natural white oak populations in Europe, applying both microsatellites and individual-based genetic assignment methods, justify separate taxonomical units for the oak species (reviewed by VISCOSI et al., 2009). Specific regions in the genomes were shown to be more divergent than others, indicating that selection operates on a subset of loci and that species integrity is maintained despite important gene flow (ScotTi-SAINTAGNe et al., 2004; LEXeR et al., 2006).

Introgressed individuals originating from varying numbers of generations of backcrossing between fertile hybrids and the parental species and by mating among hybrids, may be difficult or even impossible to separate morphologically from the parental species. The final identification of ambiguous individuals in the field frequently depends on arbitrary cut off values of some carefully selected characters, as described in field floras. KLEINSCHMIT et al. (1995) analysed in depth experimental crosses between the two sympatric species $Q$. robur and $Q$. petraea and observed a tendency of matroclinal inheritance of morphological leaf characters in the juvenile phase resulting in a hampered morphological separation between mother species and F1 hybrids. CURTU et al. (2007) and GUGERLI et al. (2007) demonstrated that hybrids, as defined by genetic assignment, did not necessarily show intermediate morphologies and that intermediate morphologies did not systematically meant hybridization. These results confirmed the polygenic nature of morphological characters in oak. Phenotypic plasticity and interspecific variability could be responsible for morphological features that are inadequate for quantifying the degree of hybridization.
KREMER et al. (2002) performed a pan-European study of leaf morphological data of mixed $Q$. petraea and $Q$. robur stands and provided a unifying formula to distinguish $Q$. petraea from $Q$. robur. This discriminant function works better in Southern European countries in comparison to more northern (including The Netherlands and Great Britain): in Southern countries rather pure species or introgressed individuals that resemble the parental species are present in mixed stands, whereas in northern countries more intermediate phenotypes can be observed (see also JENSEN et al., 2009). The discriminant function is very useful for foresters and ecologists. Still, taxonomists have to decide if they stick to the two taxa $Q$. robur and $Q$. petraea (to the result of the discriminant function), if they lump both species, or, if they define the two species along with a morphologically identifiable $Q$. x rosacea.

Our contribution is an in depth morphological analysis of five autochthonous Flemish sessile oak stands including not only leaf characters, which is largely the case in morphological oak studies, but also fruit data. Autochthonous is interpreted here as defined by KLEINSCHMIT et al. (2004) indicating populations that show a continuous presence since their post glacial colonisation. Several studies reconstructed the post-glacial migration routes of oaks in Europe using both palynological research and maternally inherited chloroplast markers (BREWER et al., 2002; PETIT et al., 2002). In Flanders, autochthonous oak populations originate from the refugia in the Italian and Iberian peninsulas (COART et al., 2001; VANDER MiJnsbrugGe et al., 2003). The studied stands in this paper all belong to the Italian migration route and contain a putative hybrid swarm. Because they show a monotypic cpDNA profile and because they are remnants of old coppice practice, they are believed to be autochthonous. Coppice is an old pre-medieval practice and the oaks were not planted, or if so, only with local material. This study analyses these five stands morphologically to identify characters with a potency to identify putative hybrids and to look for putative local morphological characters correlated with the variation in juvenile growth of derived planting stock.

\section{Materials and Methods}

\section{Study species}

According to the two field floras available for the Low Countries $Q$. robur is characterised by a short leaf petiole length and a large fruit petiole length. Vice versa, $Q$. petraea exhibits a long leaf petiole length and a short fruit petiole length (Table 1). A third diagnostic character described in these floras is the presence $(Q$. robur) or absence $(Q$. petraea $)$ of ears at the base of the leaf lamina. In Flora Europaea (TUTIN et al. 1964-1993) the contrasting petiole lengths of leaf and fruit are reported, but the presence of a leaf ear is not explicitly added to the morphological explanations. In contrast to the two field floras, Flora Europaea depicts the level of hairiness on the lower side of the leaf: glabrous or pubescent in young leaves for $Q$. robur and finely appressed hairy for $Q$. petraea. In addition, this flora focuses on the intercalary veins: several are present in the leaves of 
Table 1. - Limits of leaf and fruit petiole lengths between $Q$. robur and Q. petraea as defined by field floras in Belgium and the Netherlands and Flora Europaea.

\begin{tabular}{lllll}
\hline flora & \multicolumn{2}{l}{ leaf petiole length (mm) } & \multicolumn{2}{l}{ fruit petiole length (mm) } \\
\cline { 2 - 5 } & Q. robur & Q. petraea & Q. robur & Q.petraea \\
\hline Lambinon et al. (1998) & $5-10$ & $10-30$ & long & short \\
field flora & & & & \\
van der Meijden (2005) & $0-3(-7)$ & $10-25$ & $20-90$ & very short \\
field flora & & & & \\
Tutin et al. (1964-1993) & $0-5$ & $18-25$ & $10 n g$ & short or absent \\
Flora Europaea & & & & \\
This analysis & $0-10$ & $11-30$ & $21-90$ & $0-20$ \\
\hline
\end{tabular}

$Q$. robur and they are usually present, at least near the base of the leaf, for $Q$. petraea.

\section{Study stands}

Five stands containing $Q$. petraea that are considered as autochthonous in a field evaluation (RöVEKAMP and Maes, 1999; Opstaele, 2001), all of them being remnants of former coppice practice, were sampled. They are located in the north eastern part of Flanders on nutrient poor and dry sandy soils (Fig. 1) and they all belong to the Italian post glaciation migration route (Vander Mijnsbrugge et al., 2003). Stand age is impossible to verify as the trees were most probably not planted and stems were regularly cut during coppice practice in former centuries, so no original stem material is present anymore. Also below ground, older roots may have died off in favour of new growth over longer time spans. Varying proportions of $Q$. petraea and $Q$. robur are present and the field evaluations indicate the presence of $Q$. $x$ rosacea in all five. For the morphological evaluation of $Q$. $x$ rosacea, the field inventories followed the floras of LAMBINON et al. (1998) and Heukels (van der Meijden, 2005).

\section{Sampling}

In every stand 30 adult trees were sampled randomly for both leaves and fruits. Sampling was performed at the end of September 2007 at a moment that acorns were still present on the trees and also considerable amounts had fallen on the ground. 2007 was a mast-fruiting year. Preference was given to sampling of twigs that hold both leaves and fruits at the outside of the crown. Because the five stands are relicts of former coppice practice, the stem density of the stands is relatively low and crowns of many trees expand to lower levels where branches with both leaves and acorns could easily be cut. At some places, stem densities were locally higher. Here leaved branches were still accessible, but no fruits were present on the shadowed branches and acorns were collected from the soil. Only fruits lying at a maximum distance of $1 \mathrm{~m}$ from the stem were taken. Up to three fully expanded leaves were sampled per tree. KREMER et al. (2002) showed that analysing three leaves per tree is satisfying for a morphological study. As far as possible, leaves were insect damage and disease free. Three fully developed fruits (fruit petiole with attached acorns) per tree were picked from a branch, or collected from the soil as

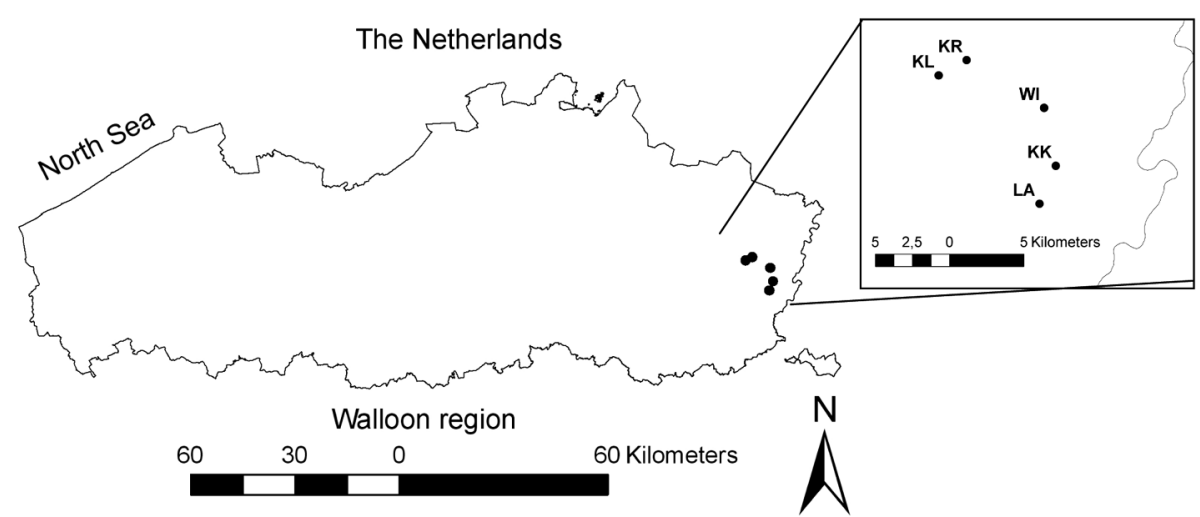

Figure 1. - Location of the five sampled autochthonous oak stands in Flanders. KL: Klaverberg, KR: Kruisberg, LA: Langenberg, KK: Kikbeekbron, WI: Windelsteen. 
described above. Similar to the leaves, fruits were selected with acorns that looked insect damage and disease free. Per fruit one representative and fully developed acorn was chosen for measurements (see lower).

\section{Leaf and fruit measurements}

Several characters were measured, counted or observed on the leaves and fruits (Table 2 and Fig. 2).
Leaf characters follow KREMER et al. (2002) with minor modifications. Fruit characters were chosen based on their putative diagnostic value. LL, PL, WP, LW1, LW2, SW1, SW2, BW1, EL, AL, AW, FP1 and FP2 were measured using a rod. Each individual leaf was classified according to the presence or absence of a leaf ear at the lamina base. Hence, EL or BW1 were measured respectively (Fig. 2a). In many cases, both types of leaves were

Table 2. - Overview of characters applied to describe Q. robur and Q. petraea in this study.

\begin{tabular}{|c|c|c|c|}
\hline organ & character & $\mathrm{Ab}$. & description \\
\hline \multirow[t]{27}{*}{ leaf } & lamina length & LL & length of the leaf lamina \\
\hline & petiole length & PL & length of the leaf petiole \\
\hline & $\begin{array}{l}\text { partial length } \\
\text { lamina }\end{array}$ & WP & length of basal part of lamina till largest width \\
\hline & lobe width & LW1 & lobe width at widest side of leaf \\
\hline & & LW2 & lobe width at other side of leaf than LW1 \\
\hline & sinus width & SW1 & width of sinus below LW1 \\
\hline & & SW2 & width of sinus below LW2 \\
\hline & number of lobes & NL & $\begin{array}{l}\text { number of lobes at both sides of the leaf. A lobe should } \\
\text { have a clear axillary vein }\end{array}$ \\
\hline & $\begin{array}{l}\text { number of } \\
\text { intercalary veins }\end{array}$ & NV & $\begin{array}{l}\text { number of veins running from the mid vein up to a sinus, } \\
\text { counted at both sides of the leaf }\end{array}$ \\
\hline & abaxial pubescence & PU & $\begin{array}{l}\text { abaxial laminar pubescence scored from } 1 \text { (no } \\
\text { pubescence) to } 6 \text { (dense hairiness), considering stellate } \\
\text { and simple hairs together. }\end{array}$ \\
\hline & $\begin{array}{l}\text { basal lamina } \\
\text { width }^{(1)}\end{array}$ & BW1 & $\begin{array}{l}\text { width of lamina base at } 1 / 20^{\text {th }} \text { of total lamina length } \\
\text { (before onset of first lobe) at widest side of leaf }\end{array}$ \\
\hline & ear length ${ }^{(2)}$ & EL & length of longest leaf ear at base of lamina \\
\hline & lamina shape & LS & $100 \times(\mathrm{WP} 1+\mathrm{WP} 2) / \mathrm{LL}$ \\
\hline & petiole ratio & PR & $100 \times \mathrm{PL} /(\mathrm{PL}+\mathrm{LL})$ \\
\hline & lobe depth ratio & LDR & $100 \times(L W 1-S W 1) / L W 1$ \\
\hline & $\begin{array}{l}\text { percentage } \\
\text { intercalary venation }\end{array}$ & PV & $100 \times \mathrm{NV} / \mathrm{NL}$ \\
\hline & lobe width ratio & LWR & $100 \times \mathrm{LW} / \mathrm{LL}$ \\
\hline & leaf asymmetry & LA & LW1 - LW2 \\
\hline & $\begin{array}{l}\text { leaf asymmetry } \\
\text { ratio }\end{array}$ & LAR & $100 \times(L W 1-L W 2) / L W 1$ \\
\hline & ear length ratio & ELR & $100 \times \mathrm{EL} /(\mathrm{EL}+\mathrm{LL})$ \\
\hline & basal width ratio & BWR & $100 \times(B W 1 / L W 1)$ \\
\hline & leaf base class & LBC & $1: \mathrm{BWR}<17,5$ \\
\hline & & & $2: \mathrm{BWR}=17,5-22,9$ \\
\hline & & & 3: $\mathrm{BWR}>23$ \\
\hline & & & 4: $\operatorname{ELR}<2,3$ \\
\hline & & & $5: E L R=2,3-3,2$ \\
\hline & & & 6: ELR > 3,2 \\
\hline \multirow[t]{9}{*}{ fruit } & acorn length & $\mathrm{AL}$ & length of acorn \\
\hline & acorn width & $\mathrm{AW}$ & width of acorn \\
\hline & fruit petiole length & FP1 & total length of fruit petiole \\
\hline & $\begin{array}{l}\text { partial fruit petiole } \\
\text { length }\end{array}$ & FP2 & $\begin{array}{l}\text { length of fruit petiole from onset to first acorn (fully } \\
\text { developed or small) }\end{array}$ \\
\hline & $\begin{array}{l}\text { number of } \\
\text { developed acorns }\end{array}$ & NA1 & number of fully developed acorns on one fruit petiole \\
\hline & $\begin{array}{l}\text { number of } \\
\text { undeveloped acorns }\end{array}$ & NA2 & $\begin{array}{l}\text { number of small, undeveloped acorns on one fruit } \\
\text { petiole }\end{array}$ \\
\hline & $\begin{array}{l}\text { total number of } \\
\text { acorns }\end{array}$ & TA & $\mathrm{NA} 1+\mathrm{NA} 2$ \\
\hline & acorn shape & AS & $100 \mathrm{X}(\mathrm{AL} / \mathrm{AW})$ \\
\hline & fruit petiole ratio & FPR & $100 \mathrm{X}(\mathrm{FP} 2 / \mathrm{FP} 1)$ \\
\hline
\end{tabular}

Ab.: abbreviation.

(1) leaf lamina base without leaf ear.

${ }^{(2)}$ leaf lamina base with leaf ear. 
present on one tree (three leaves were measured per tree). NL, NV, NA1 and NA2 were counted. The density of pubescence on the lower side of the leaf lamina (PU) was scored from 1 (glabrous) to 6 (densely pubescent). From these measured, counted or observed characters, several transformed variables were derived (Table 2).

\section{Data analysis}

We explored the data with summary statistics, box and whisker plots and scatter plots. For data analysis we applied the Principal Component Analysis (PCA) and K-means clustering, all available in Splus 6.2 Professional (Insightful Corp.) using the mean values of the three leaves and fruits per tree. As the three measured leaves per tree often belonged to both types, the ones with and the ones without leaf ears, the characters describing the leaf base were analysed separately and a categorical character 'leaf base class' (LBC, Table 2) was created with values ranging from 1 (most extreme $Q$. petraea leaf) to 6 (most extreme $Q$. robur leaf). The limits between the different categories were defined arbitrarily.

a

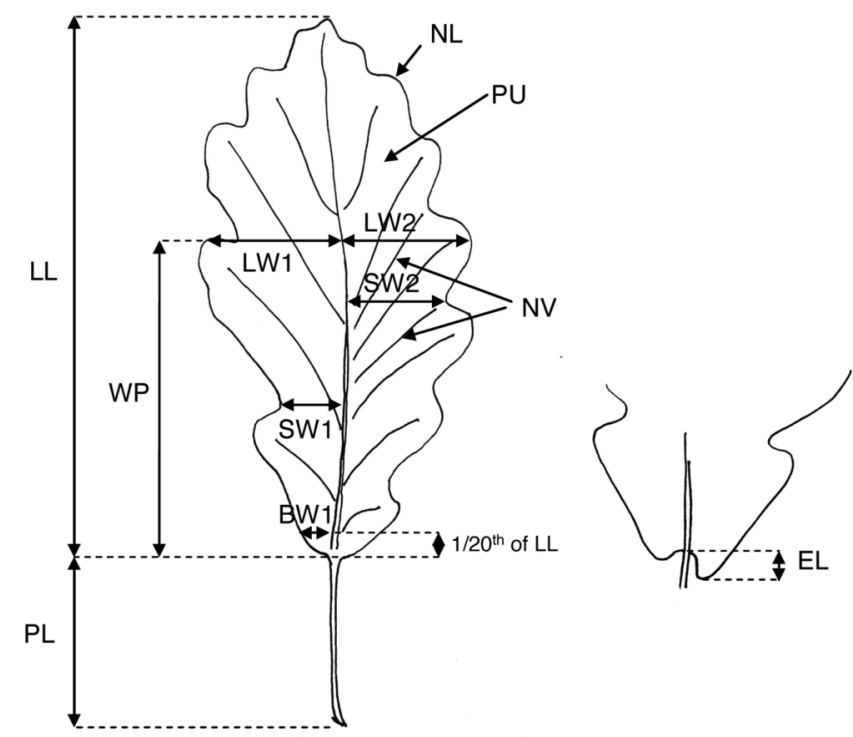

b

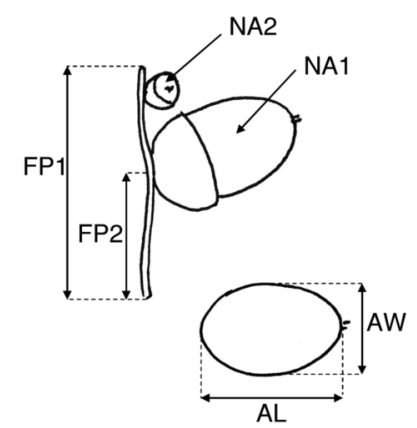

Figure 2. - Morphological leaf (a) and fruit (b) characters that were measured, counted or observed. Abbreviations of characters are in Table 2.

\section{Results}

Discrimination between $Q$. robur and $Q$. petraea based on leaf and fruit data

Overall PCAs, including both primary characters and derived variables, show a continuous cloud in a biplot of the first two components when leaf or fruit data are processed separately (Fig. $3 a$ and $b$ ). When leaf and fruit data are taken together, a bimodal distribution along the first axis becomes visible (Fig. 3c). SW1, SW2, FP2, LL, FP1, NL, PL, LW2, LW1, NV (Table 2) are important characters, in decreasing order, according to the PCA loadings of the first axis. PU is only moderately important here, although the correlation coefficient with $\mathrm{PL}$ is $49 \%$ (NV and SW1 are correlated 52 and 51\% with $\mathrm{PL})$. When the discriminant function for oak identification $(\mathrm{ID}=357-(97 \mathrm{X} \mathrm{PL})+(205 \mathrm{X} \mathrm{NV}))$ as proposed by KREMER et al. (2002) was applied to our morphological leaf data set, $12 \%$ was misclassified as $Q$. petraea in stead of $Q$. robur, in comparison to a K-means clustering into two groups of the total dataset including leaf and acorn data. The reason is a stricter counting of the intercalary veins $(\mathrm{NV})$ in our study, as we only considered the veins running from the mid vein close to or to the sinus, whereas in the KREMER et al. (2002) study shorter veins that pointed towards the sinus were also included. A smaller number of $\mathrm{NV}$ in the formula lowers the ID value and thus enhances the misqualification of $Q$. robur in $Q$. petraea.

\section{Where are the putative hybrids situated?}

Putative hybrids and introgressed individuals, further termed 'hybrids', can be defined by the PL and FP1 ranges present in the field floras available for the Low Countries (Table 1): they show a PL of $Q$. robur and a FP1 of $Q$. petraea, or vice versa. This can be visualised in a PCA (Fig. 3c) or in a scatter plot of PL and FP1 (Fig. 4a). In the scatter plot, the hybrids are present in the first and third quadrant of the plot when the limits of PL and FP1 distinguishing both parental oak species are interpreted as axes. Interestingly, NA2 but not NA1 is variable across the different taxa, as visualised in the box and whisker plots in Fig. 5. The averages of the relative number of developed acorns (NA1/TA) of the trees in the different quadrants of the scatter plot in Fig. $4 a$ is lower in both groups of hybrids in comparison to the $Q$. robur or $Q$. petraea group to which they belong considering only the PL limit.

\section{An alternative way of defining hybrids}

An alternative way of defining hybrids is delineating two arbitrary zones, based on a priori limits, of small but equal size close to the diagonal that separates the two clouds of $Q$. robur and $Q$. petraea in the scatterplot of PL and FP1 (Fig. 4b). This is based on the assumption that hybrid individuals show intermediate forms between the parental species for both characters. Here, the mean NA1/TA value becomes lower for the thus defined hybrids in the zone close to the $Q$. robur group than for the hybrids in the zone close to $Q$. petraea. This is not expected as the value of NA1/TA for $Q$. robur is higher than for $Q$. petraea. It can be noticed that the 
a
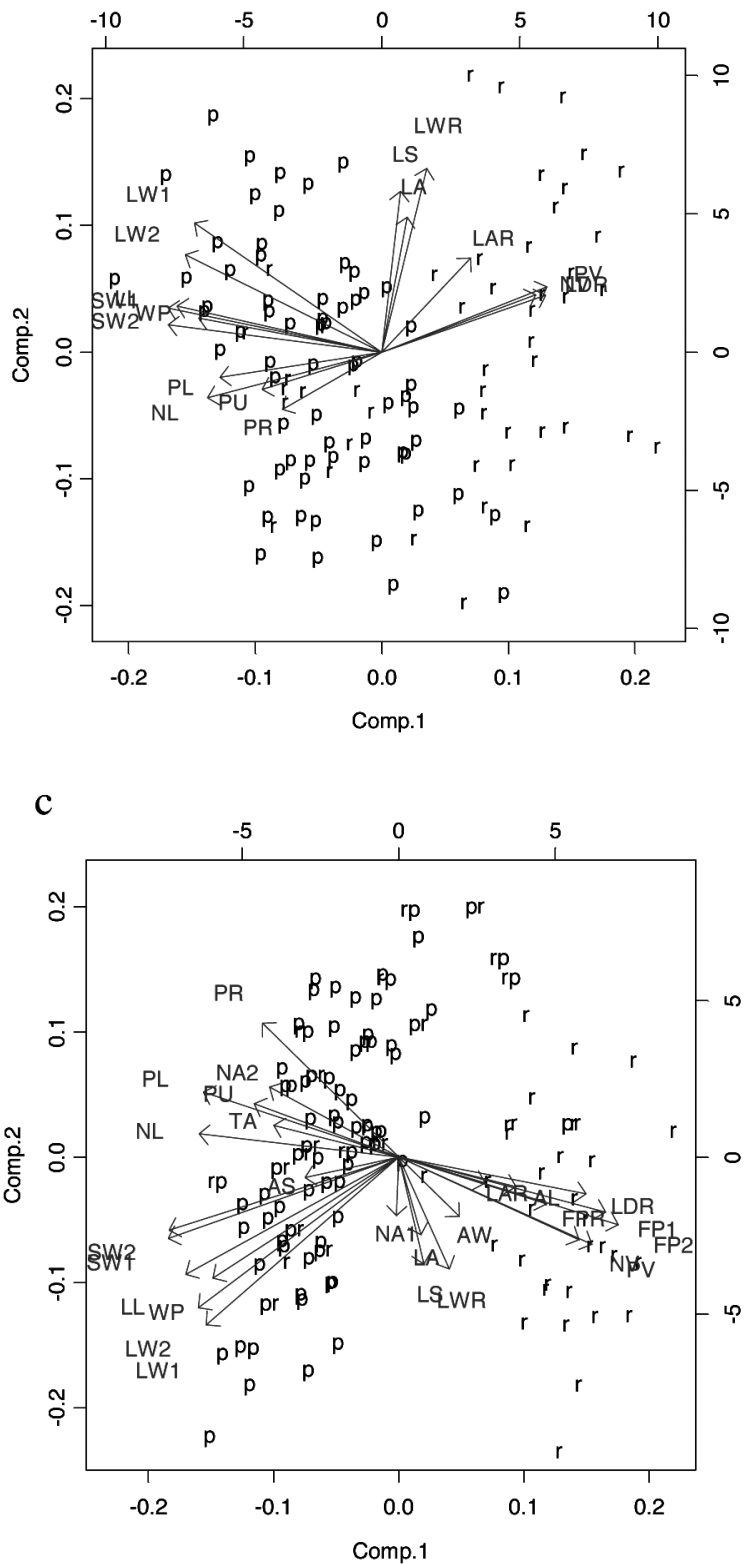

hybrids close to the $Q$. petraea group are concentrated mainly in the third quadrant of the plot, with a low PL value, whereas the hybrids close to the $Q$. robur group are more divided among the third, fourth and first quadrant of the plot, including individuals with a higher PL.

\section{Importance of the shape of the leaf lamina base for species distinction}

When leaves are divided into $Q$. robur or $Q$. petraea based only on the presence or absence of a leaf ear at the lamina base, $66 \%$ is classified as $Q$. petraea and $34 \%$ as Q. robur. When the leaf lamina base is divided in 6 classes (LBC, Table 2), this variable correlates best with NL, LL and PL (correlation coefficients of $41 \%, 40 \%$ and $37 \%$ respectively). When the trees are divided in two groups based on a K-means clustering, which includes all characters unless the ones that define the leaf ear, $67 \%$ is classified as Q. petraea and $33 \%$ as Q. robur.

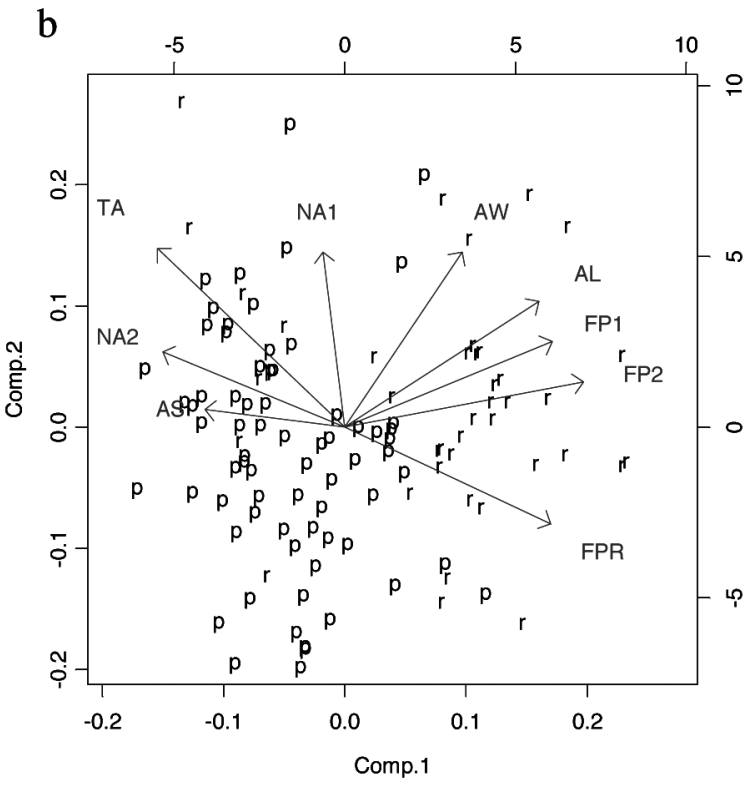

Figure 3. - Biplots of PCAs using the morphological leaf and fruit character data (Table 2), except for the leaf base characters BW1, BW2, EL, EW and characters derived from these. a) PCA of only leaf characters. The first two components explain 44,1 and $14,7 \%$ of the variation. Labelling is according to the leaf petiole length. $\mathrm{p}: \mathrm{PL}>10 \mathrm{~mm} ; \mathrm{r}$ : PL $\leq 10 \mathrm{~mm}$. b) PCA of only fruit characters. The first two components explain 38,1 and $18,1 \%$ of the variation. Labelling is according to the fruit petiole length. p: FP1 $\leq 20 \mathrm{~mm}$; r: FP1 $>20 \mathrm{~mm}$. c) PCA of both leaf and fruit characters. The first two components explain 37,3 and $10,4 \%$ of the variation. Labelling is according to the leaf and fruit petiole lengths. $\mathrm{p}: \mathrm{PL}>10 \mathrm{~mm}$ and FP1 $\leq 20 \mathrm{~mm}$; : PL $\leq 10 \mathrm{~mm}$ and FP1 $>20 \mathrm{~mm}$; rp: PL > $10 \mathrm{~mm}$ and FP1 > $20 \mathrm{~mm}$; pr: $\mathrm{PL} \leq 10 \mathrm{~mm}$ and FP1 $\leq 20 \mathrm{~mm}$.

This is remarkably similar with the percentages derived from the shape of the leaf lamina base, as on an individual level, the leaf lamina base classes are quite variable. In the biplot of a PCA of all leaf and fruit characters, excluding the ones that define the shape of the lamina base, with the trees labelled according to LBC, one would expect in the $Q$. robur group only the classes 4,5 and 6 whereas in the opposite group only 1,2 and 3 . But, this is not the case (Fig. 6a). The scores of the first component of this PCA, along which $Q$. robur and $Q$. petraea can be discriminated, can be grouped according to the LBC class in a box and whisker plot (Fig. 6b). For leaves without a leaf ear (LBC classes 1 to 3 ), the basal width ratio (BWR) seems not to influence the position of the trees along the first component of the PCA. In the case of leaves with a leaf ear, the ear length ratio (ELR) tends to augment with an increasing first component score. 
a

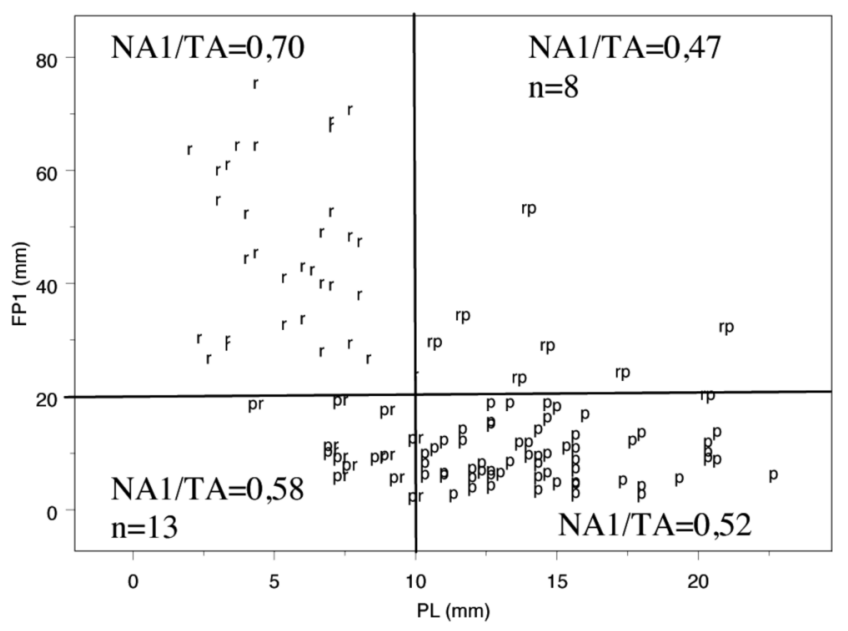

b

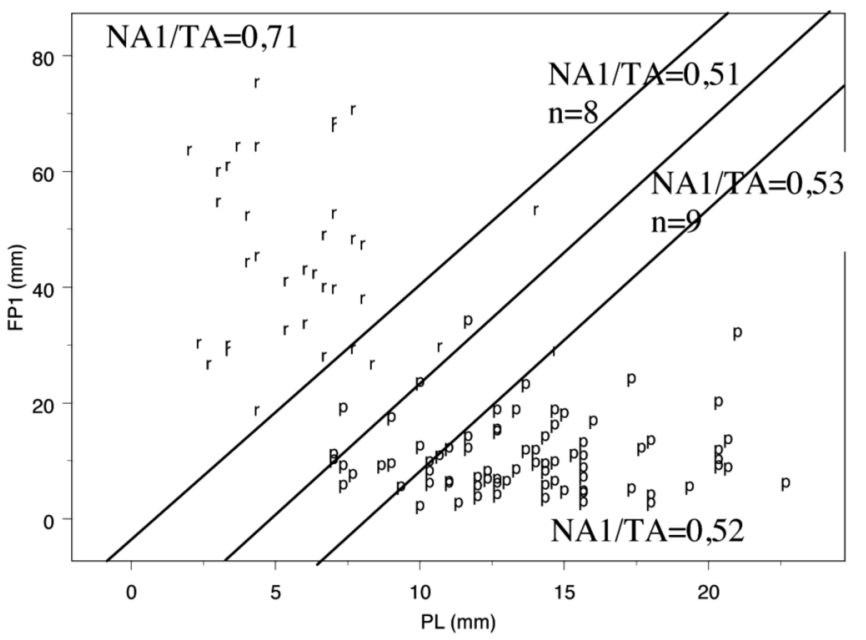

Figure 4. - Scatter plots of leaf petiole length (PL) and fruit petiole length (FP1) with a calculation of the mean relative number of developed acorns (NA1/TA). a) The lines that indicate the limits between $Q$. robur and $Q$. petraea for the characters PL and FP1 are drawn. Labelling is according to the leaf and fruit petiole lengths. p: $\mathrm{PL}>10 \mathrm{~mm}$ and $\mathrm{FP} 1 \leq 20 \mathrm{~mm}$; r: PL $\leq 10 \mathrm{~mm}$ and FP1 > $20 \mathrm{~mm}$; rp: PL > $10 \mathrm{~mm}$ and FP1 > $20 \mathrm{~mm}$; pr: PL $\leq 10 \mathrm{~mm}$ and FP1 $\leq 20 \mathrm{~mm}$. b) The middle diagonal line indicates a visual and thus arbitrary limit between $Q$. robur and $Q$. petraea. Species designation and labelling is according to a K-means clustering analysis of the total data set into two groups. r: Q. robur; p: Q. petraea. Two parallel lines at each side are drawn arbitrarily to create a putative hybrid zone.

\section{Discussion}

\section{Bimodal distribution}

We observed no continuous morphological transition from $Q$. robur to $Q$. petraea but two obvious clusters with restricted overlap when both leaf and fruit data were processed together in a PCA. Only leaf data do not make this apparent distinction between the two species, which is not in concordance with the findings of KREMER et al. (2002), who found a bimodal distribution based only on leaf characters in a pan-European dataset. Possibly our dataset is too small in comparison to KREMER et al. (2002). This result suggests that fruit data may be critical in morphological species distinction between $Q$. robur and $Q$. petraea when only limited data sets are available. Surprisingly, PU is not among the most correlated characters with the first component in the PCA of our dataset. This deviates from the observations in KREMER et al. (2002) and VISCOSI et al. (2009). It could be a local phenomenon in our geographically small scale study area. The absence or presence of a leaf ear at the lamina base, a character traditionally used by many field workers to separate the two species, is not reliable. In our dataset, quite some $Q$. petraea trees that cluster close to the $Q$. robur group in a PCA analysis have a small leaf ear (Fig. 6b).

\section{A lowered relative number of developed acorns in putative hybrids}

In the pan-European dataset of KREMER et al. (2002) hybrids do not form a third population apart from
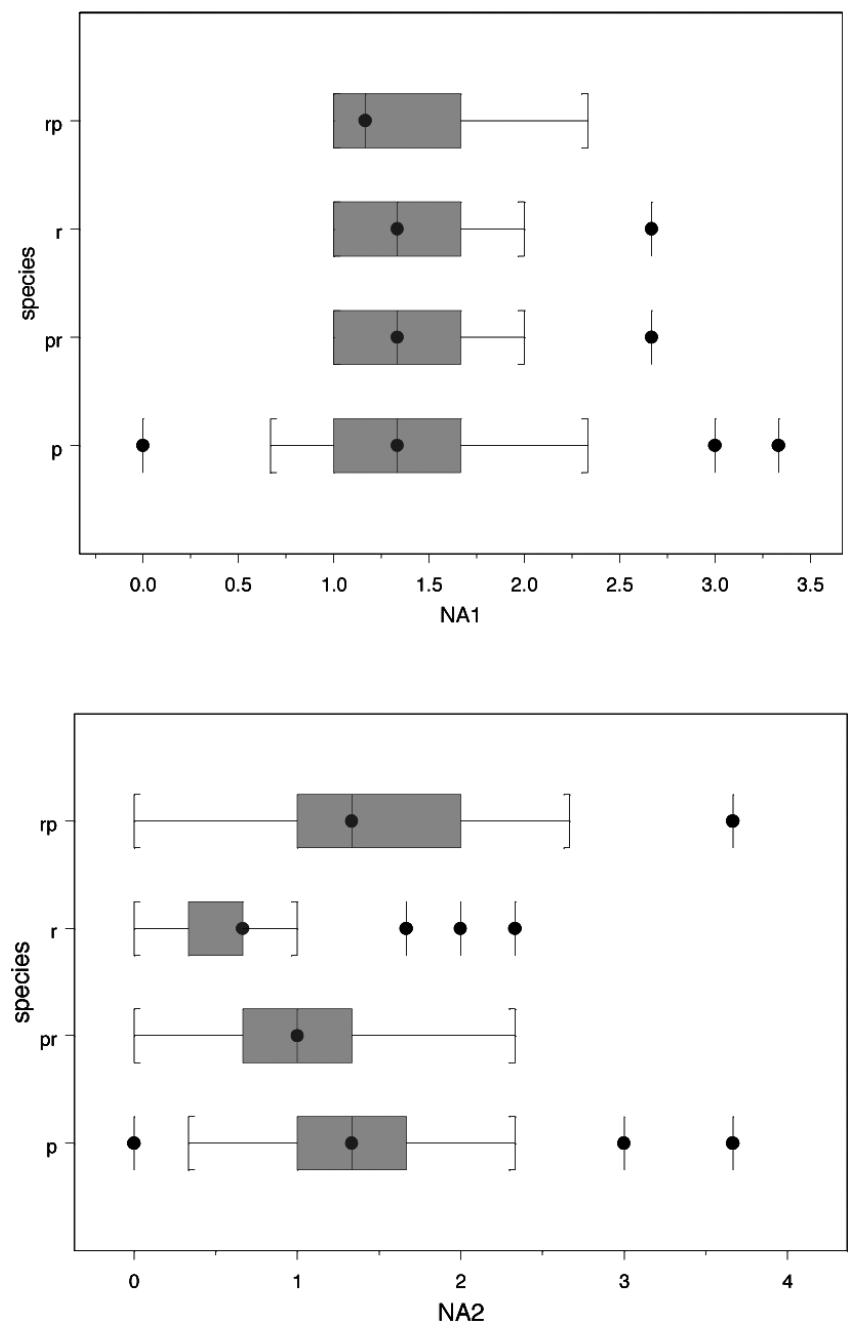

Figure 5. - Box and whisker plots of the number of developed (NA1) and undeveloped acorns (NA2) divided among the species and hybrid groups based on PL and FP1 limits. p: PL > $10 \mathrm{~mm}$ and FP1 $\leq 20 \mathrm{~mm}$; $\mathrm{r}: \mathrm{PL} \leq 10 \mathrm{~mm}$ and $\mathrm{FP} 1>20 \mathrm{~mm}$; rp: PL $>10 \mathrm{~mm}$ and FP1 $>20 \mathrm{~mm}$; pr: $\mathrm{PL} \leq 10 \mathrm{~mm}$ and $\mathrm{FP} 1 \leq$ $20 \mathrm{~mm}$. 
$Q$. robur and $Q$. petraea, although the natural occurrence of hybrids between the two species has been proven before. Based on three assumptions, the relative number of developed acorns (NA1/TA) can become a predictor of the putative hybrid or introgressed status. The first assumption is matroclinal inheritance of the leaf character PL (matroclinal inheritance of leaf characters has been observed in oak by KLEINSCHMIT et al., 1995). The second is a matroclinal inheritance of the capacity for successful fertilisation and development of sound acorns. Thirdly, we assume that the individuals that produce a lower number of developed acorns in comparison to those of the putative maternal species, are hybrids or introgressed individuals (termed hybrids further on). Accepting these three assumptions, a lower mean relative number of developed acorns was observed

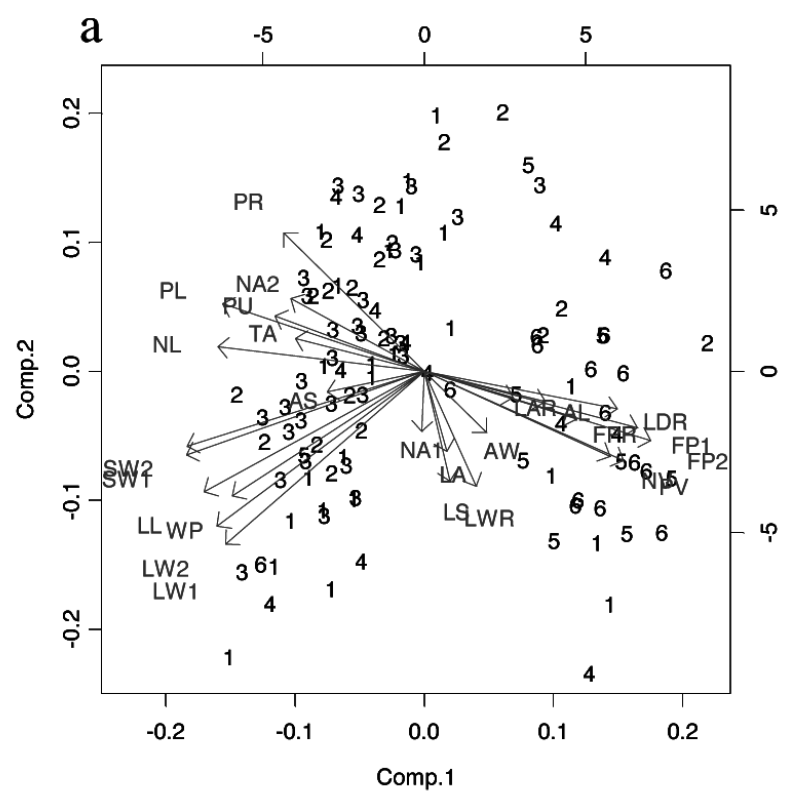

b

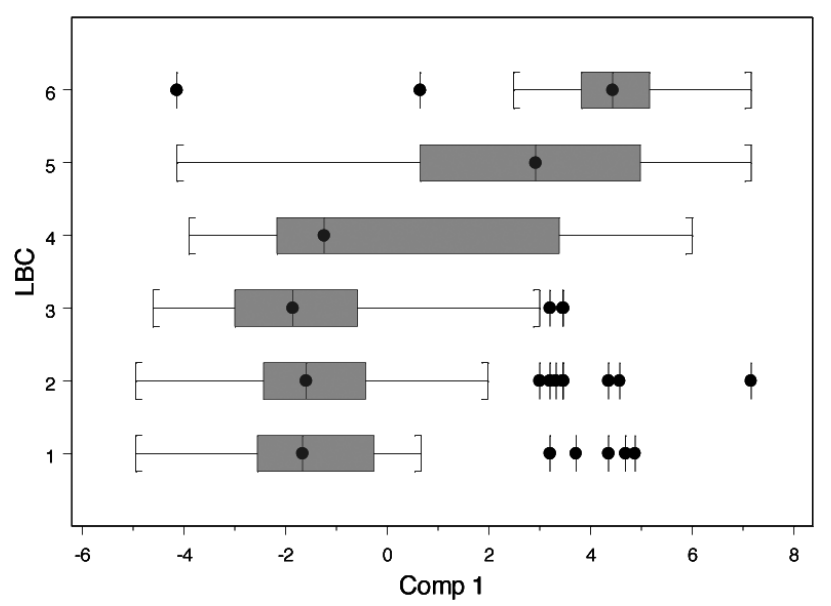

Figure 6. - Evaluation of leaf lamina base. a) Biplot of the PCA in Fig. $3 c$ labelled according to the leaf base class (LBC) of one random leaf per tree. b) Box and whisker plot of the scores of the first component of the PCA analysis in Fig. $3 c$ grouped according to the leaf base class (LBC) values of all leaves. in the hybrid individuals defined according to two field flora limits for PL and FP1 (Fig. 4a). Hybrids with $Q$. robur as a mother tree will inherit PL from $Q$. robur and thus FP1 from the pollinating $Q$. petraea. The relative number of developed acorns is in this group, on average, lower than for $Q$. robur, the maternal parent, indicating the hybrid status. Still the relative number of developed acorns in this hybrid group is higher in comparison to the hybrids that have $Q$. petraea as a mother tree, because in this group the relative number of developed acorns decreases below the average of the $Q$. petraea parent. This could indicate the superiority of PL, a leaf character, above FP1, a fruit character, as a measure for successful development of acorns. It reinforces the observance of maternal inheritance of leaf characters on juvenile individuals (KLEINSCHMIT et al., 1995). The reduced mean NA1/TA in the above defined hybrids in comparison to the trees that belong to their putative maternal species may suggest a reduced ability to produce fully developed acorns, which might be an indicator of the hybrid status. These results also indicate the importance of discriminating between two types of hybrids dependant on which species is maternal or paternal and underpins the observation that hybrid groups in general are not homogenous (ARNOLD, 1997; VISCOSI et al., 2009).

\section{The absence of a continuous morphological hybrid swarm}

Defining hybrids in the small intermediate zone where the distributions of $Q$. robur and $Q$. petraea overlap in an PL - FP1 scatterplot, does not improve the ability of NA1/TA to predict the putative hybrid status, according to the three assumptions described above. This implies that classifying hybrids based on PL and FP1 limits, as described in different floras, is quite appropriate and that based only on leaf characters hybrids can remain unidentifiable. A lowered ability for successful fertilisation and sound acorn development in hybrids, as hypothesised above, is in accordance with the fact that the two sympatric species did not evolve to a complete spectrum of introgressed forms and thus to one continuous range of morphological variation that would be no more distinguishable from the intraspecific variation, which would have evolved from repeated backcrosses over several generations. All together, it is also a good argument for taxonomists to stick to the taxon $Q$. $x$ rosacea for individuals with intermediate morphology based on the defined PL and FP1 limits, in the absence of genetic data.

\section{Differentiation between the individual stands}

In the framework of a conservation program of autochthonous genetic resources of woody plants in Flanders, planting stock of the autochthonous oak stands is grown and marketed (VANDER MIJNSBRUGGE et al., 2005). To test the putative value of old coppice derived material, provenance trials were set up. Early trial data indicates that planting stock derived from Klaverberg and Kruisberg shows a limited height growth in the juvenile phase in comparison to the other three stands Windelsteen, Langenberg and Kikbeekbron 


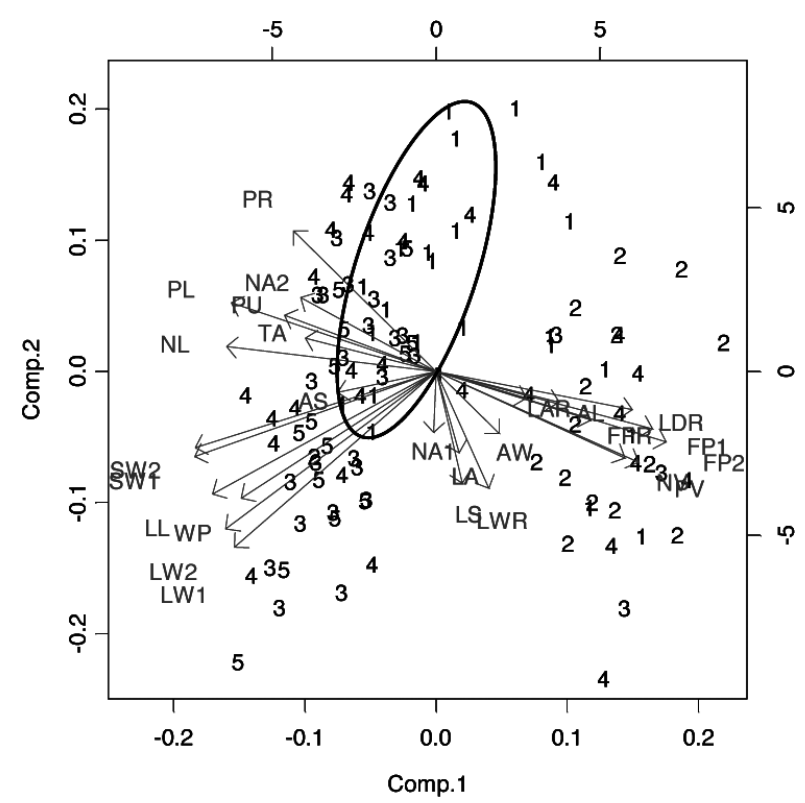

Figure 7. - Biplot of the PCA in Fig. $3 c$ labelled according to a stand number. 1: Klaverberg; 2: Kruisberg; 3: Langenberg; 4: Kikbeekbron; 5: Windelsteen. The concentration of Klaverberg trees in the $Q$. petraea cloud is indicated with an ellips.

(will be published elsewhere). Therefore, we looked at a putative morphological divergence between the stands. Morphologically, Kruisberg consists mainly of $Q$. robur whereas the other studied stands contain larger amounts of $Q$. petraea, although this cannot justify the slow juvenile growth. For Klaverberg, the individuals that are located in the $Q$. petraea cloud in the PCA biplot of leaf and fruit data, have a tendency to group closer to the $Q$. robur cloud (along the first component) and also to relatively small and symmetric leaves (along the second component) (Fig. 7). Although all five studied stands are considered autochthonous based on both a field evaluation (old coppice relicts) and a cpDNA analysis (uniform Italian migration lineage), the tendency towards a morphological concentration of the $Q$. petraea group in Klaverberg in comparison to the other stands, together with the slower juvenile growth of Klaverberg and Kruisberg, might indicate an evolutionary divergence from the other three stands after post glacial colonisation. A late $18^{\text {th }}$ century map of Ferraris (DE KEERSMAEKER et al., 2001) supports this possibility: both Klaverberg and Kruisberg are situated in an area of mobile inland sand dunes, whereas the other three are located in other vegetation types (forest, forest with coppice and heath).

\section{Conclusion}

The combination of basic morphological fruit and leaf characters in a regular PCA analysis can clearly distinguish between the sympatric species $Q$. robur and $Q$. petraea in our studied mixed oak stands, whereas only leaf or fruit characters cannot. Putative hybrids or introgressed individuals between the two can be identified based on leaf and fruit petiole lengths. The relative number of developed acorns on the fruit petioles might be an indicator for the hybrid or introgressed status of the tree. Together with formerly observed matroclinal inheritance, our results suggest that mixed oak stands consist mainly of morphologically separate groups of both studied species, and that hybrids and introgressed individuals can be present within these groups. It can be hypothesised that this may be true for other related indigenous trees species that hybridise naturally in the areas where their distributions overlap, but where they did not evolve in continuous morphological groups. For future research, combining genetic marker data with our morphological data set might give a deeper and more complete view of the morphological consequences of hybridization. In particular, genetic assignment tests could prove the value of the suggested fruit characters as easy field indicators for the hybrid status of a tree. Finally, leaf trichomes were recently described as a diagnostic character to distinguish $Q$. robur and $Q$. petraea (FORTINI et al., 2009) and should be tested for hybrid identification.

\section{Acknowledgments}

We like to thank in the first place FRANCIS DE MoL for the measurements on the oak herbarium during his training period at the Research Institute for Nature and Forest. Francis, together with David Halfmaerten, NANCy Van LiefFertinge and StefaAn Moreels, were very helpful during the collection of the plant material. In addition, we are most grateful to STEFAAN MOREELS for indispensable technical and supportive assistance during the whole study.

\section{References}

ARNOLD, M. L. (1997): Natural Hybridization and Evolution. Oxford Series in Ecology and Evolution. Oxford University Press, New York.

Bacilieri, R., A. Ducousso, R. J. Petit and A. Kremer (1996): Mating system and asymmetric hybridization in a mixed stand of European oaks. Evolution 50: 900-908.

Brewer, S., R. Cheddadi, J. L. Beaulieu and M. Reille (2002): The spread of deciduous Quercus throughout Europe since the last glacial period. Forest Ecology and Management 156: 27-48.

Burke, J. M. and M. L. ARNOLD (2001): Genetics and the fitness of hybrids. Annual Review of Genetics 35: 31-52.

Coart, E., X. Vekemans, M. J. Smulders, I. Wagner, J. VAN Huylenbroeck, E. Van Bockstaele and I. ROLDAN-RUIZ (2001): AFLP markers demonstrate local genetic differentiation between two indigenous oak species (Quercus robur L. and Quercus petraea (Matt.) Liebl.) in Flemish populations. Theoretical and Applied Genetics 105: 431-439.

Curtu, A. L., O. Gailing and R. Finkeldey (2007): Evidence for hybridization and introgression within a species-rich oak (Quercus spp.) community. BMC Evolutionary Biology 7: 218, doi:10.1186/1471-2148-7-218.

Curtu, A. L., O. Gailing and R. Finkeldey (2009): Patterns of contemporary hybridization inferred from paternity analysis in a four-oak-species forest. BMC Evolutionary Biology 9: 284 doi :10.1186/1471-2148-9284. 
De Keersmaeker, L., N. Rogiers, R. Lauriks and B. De Vos (2001): Ecosysteemvisie bos in Vlaanderen, Ruimtelijke uitwerking van de natuurlijke bostypes op basis van bodemgroeperingseenheden en historische boskaarten. VLINA C97/06, Ministry of the Flemish Community, Brussels.

Fortini, P., V. Viscosi, L. Maiuro, S. Fineschi and G. G. VENDRAMIN (2009): Comparative leaf surface morphology and molecular data of five oaks of the subgenus Quercus Oerst (Fagaceae). Plant Biosystems doi 10.1080/11263500902722980.

Gugerli, F., J. C. Walser, K. Dounavi, R. Holderegger and R. FinKELDEY (2007): Coincidence of small-scale spatial discontinuities in leaf morphology and nuclear microsatellite variation of Quercus petraea and $Q$. robur in a mixed forest. Annals of Botany 99: 713-722.

Jensen, J., A. LARSEN, L. Nielsen and J. CotTrell (2009): Hybridization between Quercus robur and Q. petraea in a mixed oak stand in Denmark. Annual Forest Science 66: 706 doi 10.1051/forest/2009058.

Kelleher, C. T., T. Hodkinson, G. Douglas and D. Kelly (2005): Species distinction in Irish populations of Quercus petraea and $Q$. robur: morphological versus molecular analyses. Annals of Botany 96: 1237-1246.

Kleinschmit, J. R. G., R. BAcilieri, A. KRemer and A. RolOFF (1995): Comparison of morphological traits of pedunculate oak ( $Q$. robur L.) and sessile oak (Q. petraea (Matt.) Liebl.). Silvae Genetica 44: 256-269.

KLEINSCHMit, J. R. G., D. KownATZKI and H. R. GREGoRIUs (2004): Adaptational characteristics of autochthonous populations - consequences for provenance delineation. Forest Ecology and Management 197: 213-224.

Kremer, A., J. L. Dupouey, J. D. Deans, J. Cottrell, U. Csaikl, R. Finkeldey, S. Espinel, J. Jensen, J. Kleinschmit, B. Van Dam, A. Ducousso, I. Forrest, U. Lopez de Heredia, A. Lowe, M. Tutkova, R. Munro, S. STEINHOFF and V. BADEAU (2002): Leaf morphological differentiation between Quercus robur and Quercus petraea is stable across western European mixed oak stands. Annual Forest Science 59: 777-787.

Lambinon, J., J. E. DE LANGhe, L. Delvosalle and J. Duvigneaud (1998): Flora van België, het Groothertogdom Luxemburg, Noord-Frankrijk en de aangrenzende gebieden. Nationale plantentuin van België, Meise, Belgium.

Lepais, O., R. Petit, E. Guichoux, J. Lavabre, A. Kremer and S. GERBER (2009): Species relative abundance and direction of introgression in oaks. Molecular Ecology 18: 2228-2242.

Lexer, C., A. Kremer and J. Petit (2006): Shared alleles in sympatric oaks: recurrent gene flow is a more parsimonious explanation than ancestral polymorphism. Molecular Ecology 15: 2007-2012.
MAES, N. C. M. (2007): Inheemse bomen en struiken in Nederland en Vlaanderen. Boom, Amsterdam, the Netherlands.

Opstaele, B. (2001): Autochtone bomen en struiken in de houtvesterijen Leuven en Hasselt. Ministry of the Flemish Community, Brussels.

Petit, R., S. Brewer, S. Bordács, K. Burg, R. Cheddadi, E. Coart, J. Cottrell, U. Csaikl, B. van Dam, J. D. Deans, S. Espinel, S. Fineshi, R. Finkeldey, I. Glaz, P. G. Goicoechea, J. S. Jensen, K. König, A. J. Lowe, S. F. Madsen, G. Mátyás, R. C. Munro, M. Olalde, M.-H. Pemonge, F. Popoescu, D. Slade, H. Tabbener, S. DE VRIEs, B. Ziegenhagen, J.-L. DE BeAulieu and A. KREMER (2002): Identification of refugia and postglacial colonisation routes of European white oaks based on chloroplast DNA and fossil pollen evidence. Forest Ecology and Management 156: 49-74.

Petit, R. and A. HAMPE (2006): Some evolutionary consequences of being a tree. Annual Review of Ecology, Evolution, and Systematics 37: 187-214.

RÖVEKAMP, C. and N. MAES (1999): Oorspronkelijk inheemse bomen en struiken in Vlaanderen. Een onderzoek naar autochtone genenbronnen in de Regionale Landschappen West-Vlaamse Heuvels, Vlaamse Ardennen en de houtvesterijen Hechtel en Bree. Ministry of the Flemish Community, Brussels.

Scotti-Saintagne, C., S. Mariette, I. Porth, P. G. Goicoechea, T. BARReneche, C. Bodénès, K. BRug and A. KREMER (2004): Genome scanning for interspecific differentiation between two closely related oak species (Quercus robur L. and Q. petraea (Matt.) Liebl.). Genetics 168: 1615-1626.

Streiff, R., A. Ducousso, C. Lexer, H. Steinkellner, J. G. Gloess and A. Kremer (1999): Pollen dispersal inferred from paternity analysis in a mixed oak stand of Quercus robur L. and Q. petraea (Matt.) Liebl. Molecular Ecology 7: 317-328.

Tutin, T. G. and V. H. Heywood (eds.) (1964-1993): Flora Europaea. Cambridge University Press, Cambridge.

VAN DER MEIJDEN, R. (2005): Heukels' Flora van Nederland. Noordhoff uitgevers, the Netherlands.

Vander Mijnsbrugge, K., E. Coart, H. Beeckman and J. VAN SLYCKEN (2003): Conservation measures for autochthonous oaks in Flanders. Forest Genetics 10: 207-217.

VANDER Mijnsbrugge, K., K. Cox and J. VAN Slycken (2005): Conservation approaches for autochthonous woody plants in Flanders. Silvae Genetica 54: 197-206.

Viscosi, V., O. LePais, S. Gerber and P. Fortini (2009): Leaf morphological analyses in four European oak species (Quercus) and their hybrids: A comparison of traditional and geometric morphometric methods. Plant Biosystems 143: 564-574. 